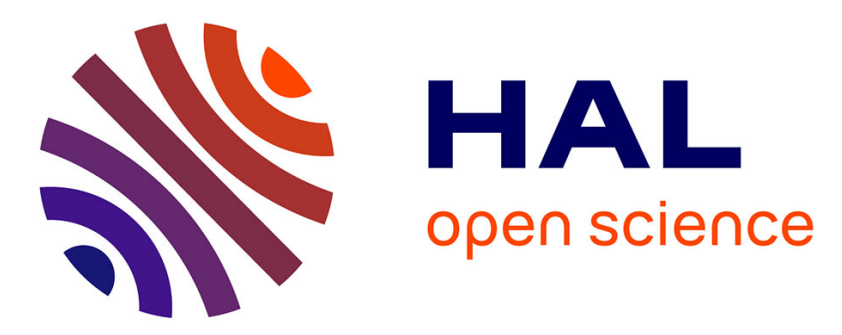

\title{
Fermentation of cow milk and/or pea milk mixtures by different starter cultures: Physico-chemical and sensorial properties
}

Manhal Yousseef, Céline Lafarge, Dominique Valentin, Samuel Lubbers, Florence Husson

\section{To cite this version:}

Manhal Yousseef, Céline Lafarge, Dominique Valentin, Samuel Lubbers, Florence Husson. Fermentation of cow milk and/or pea milk mixtures by different starter cultures: Physico-chemical and sensorial properties. LWT - Food Science and Technology, 2016, 69, pp.430-437. 10.1016/j.lwt.2016.01.060 . hal-01396424

\section{HAL Id: hal-01396424 https://u-bourgogne.hal.science/hal-01396424}

Submitted on 20 Nov 2017

HAL is a multi-disciplinary open access archive for the deposit and dissemination of scientific research documents, whether they are published or not. The documents may come from teaching and research institutions in France or abroad, or from public or private research centers.
L'archive ouverte pluridisciplinaire HAL, est destinée au dépôt et à la diffusion de documents scientifiques de niveau recherche, publiés ou non, émanant des établissements d'enseignement et de recherche français ou étrangers, des laboratoires publics ou privés. 


\title{
Fermentation of cow milk and/or pea milk mixtures by different starter cultures: Physico-chemical and sensorial properties
}

\author{
Manhal Yousseef ${ }^{a}$, Céline Lafarge ${ }^{a}$, Dominique Valentin ${ }^{\mathrm{b}}$, Samuel Lubbers ${ }^{\mathrm{a}, 1}$, \\ Florence Husson ${ }^{\text {a, * }}$ \\ a UMR Procédés Alimentaires et Microbiologiques A 02.102, AgroSup Dijon, Université de Bourgogne, 1 Esplanade Erasme, 21000 Dijon, France \\ ${ }^{\mathrm{b}}$ Centre des Sciences du Goût et de l'Alimentation, UMR6265 CNRS, INRA, Université de Bourgogne, 9E Boulevard Jeanne d'Arc, 21000 Dijon, France
}

Five mixtures of milk and pea protein $(0-40 \mathrm{~g}$ pea protein/100 $\mathrm{g}$ total protein) were fermented by ten starter cultures of lactic acid bacteria (LAB $)^{2}$ to select the cocktails that can lead to products similar to a conventional yoghurt. Generally speaking, an increase in pea concentration leads to products with higher acidity, higher syneresis and lower firmness. From the sensory perspective, up to $30 \mathrm{~g}$ pea protein/100 $\mathrm{g}$ total protein, starter cultures show either positive or negative effects. A principal component analysis $(\mathrm{PCA})^{3}$ and a hierarchical cluster analysis (HCA $)^{4}$ carried out on all variables revealed five groups of products. Two groups of products of $0 \mathrm{~g}$ or $10 \mathrm{~g}$ pea protein/100 $\mathrm{g}$ total protein seemed to be the most similar to conventional dairy products. The third group included products fermented with two starters with negative characteristics such as astringency and bitterness. The last two groups included members made of $10 \mathrm{~g}, 20 \mathrm{~g}, 30 \mathrm{~g}$ and $40 \mathrm{~g}$ pea protein/100 g total protein, among them one group showing a positive sensory profile. From this group, four starter cultures seem promising for the fermentation of milk and pea protein mixtures.
Keywords:

Pea protein

Cow milk protein

Lactic acid bacteria

Rheology

Sensory properties

\section{Introduction}

The use of plant proteins, especially pulse proteins, to extend or substitute for animal-derived products is one way to guarantee food security, sustainable production in environmental safety and health benefits (Boland et al., 2013). Successful uses of plant proteins as food ingredients depend on their functional characteristics and their sensory impacts in the final products. The positive functional properties (gelation, emulsification, foaming ...) of this protein source make it a promising food ingredient (Boye, Zare, \& Pletch, 2010; Ma et al., 2011; Swanson, 1990). One of the major pulses is pea (Pisum sativum L.). Peas are usually consumed as seed,

Abbreviations: LAB, lactic acid bacteria; PCA, principal component analysis; HCA, hierarchical cluster analysis; V.max, maximum acidification rate; T.end, the time necessary to reach $\mathrm{pH} 4.7$; $\mathrm{pH} .12 \mathrm{~h}$, the $\mathrm{pH}$ after $12 \mathrm{~h}$ of fermentation; ANOVA, analysis of variance; LSD, least significant difference.

* Corresponding author.

E-mail address: florence.husson@u-bourgogne.fr (F. Husson).

1 Co-last author.

2 Lactic acid bacteria.

3 Principal component analysis.

${ }^{4}$ Hierarchical cluster analysis flour, protein isolate (Aiking, de Boer, \& Vereijken, 2006). Pea protein is easily digestible and has a high-quality amino acid profile as well as high lysine and arginine content (Schneider \& Lacampagne, 2000), but their use is limited by undesirable sensory characteristics. The main perceived compounds in pea odor profile are described as 'green', 'grassy', 'hay-like', 'pea pod' and are generated by degradation of fatty acids during extraction processes or by microbial activity on seed during storage (Hansen, Jakobsen, \& Christensen, 2000; Murat, Bard, Dhalleine, \& Cayot, 2013). Lactic acid fermentation with selected starter cultures could improve the organoleptic characteristics of foodstuff containing pea proteins. The LAB species like Streptococcus thermophilus, Lactobacillus delbrueckii subsp. bulgaricus, Lactobacillus acidophilus, Lactobacillus helveticus ... have shown positive effects on the organoleptic properties of fermented products in terms of flavor and texture (El Soda, Abd El Wahab, Ezzat, Desmazeaud, \& Ismail, 1986; Marilley, Ampuero, Zesiger, \& Casey, 2004; Moslehishad, Mirdamadi, Ehsani, Ezzatpanah, \& Moosavi-Movahedi, 2013). Furthermore, exopolysaccharide production has been reported in most of these LAB species, which increase the viscosity and firmness, and improve the texture of yoghurts (Leroy \& De Vuyst, 2004; RuasMadiedo, Hugenholtz, \& Zoon, 2002). Mixed cultures have been 
shown to reduce more lactose in fermented soymilks than a single strain, although sometimes single cultures reduce $\mathrm{pH}$ more than mixed cultures (Wang, Yu, \& Chou, 2002). Acidification by S. thermophilus of soy beverage was faster than that of milk, but the combination of $S$. thermophilus and different LAB strains did not lead to faster acidification in soy beverage, contrary to what was observed in milk, where symbiosis seems to occur (Champagne, Green-Johnson, Raymond, Barrette, \& Buckley, 2009). Studies performed on fermented milk supplemented with a small quantity of plant protein (up to 5\%) showed positive effects on textural and rheological properties of gels, both with soy protein (Drake, Chen, Tamarapu, \& Leenanon, 2000) and lentil flour (Zare, Boye, Orsat, Champagne, \& Simpson, 2011). On the other hand, negative sensory effects have been noted in products supplemented with plant proteins. The substitution of $50 \%$ or more cow milk by soya milk in fermented milk products led to a decrease in liking that might be due, in part, to the fact that consumers were expecting the fermented milk product to taste like a regular yoghurt ( $\mathrm{Tu}$, Valentin, Husson, \& Dacremont, 2010). This last observation reveals the difficulty of assessing a new product (mixed soy and milk) when it is similar to a well-identified reference, in this case, conventional cow's milk yoghurt.

The aim of this study is to screen 10 starter cultures of seven LAB species for the fermentation of five ratios of cow protein/pea protein from 0 to $40 \mathrm{~g}$ pea protein/100 $\mathrm{g}$ total protein, in order to determine the combination of starter culture and pea concentration which gives the end product the closest to a traditional yoghurt in terms of physico-chemical and sensory attributes. The $\mathrm{pH}$ reduction during fermentation, titratable acidity, syneresis and texture properties of the final product after one, seven and 14 days of storage at $4{ }^{\circ} \mathrm{C}$ were measured. Finally, a standard descriptive analysis approach was used to compare the sensory profiles of these products with that of a cow's milk yoghurt fermented with commercial milk ferments.

\section{Materials and methods}

\subsection{Ingredients and cultures}

The pea protein isolate Nutralys ${ }^{\circledR}$ S85F was supplied by Roquette (Lestrem, France) and skim milk powder was purchased from Régilait (Saint-Martin-Belle-Roche, France). Lactose monohydrate, sodium citrate and calcium phosphate monobasic were purchased from Sigma (St. Louis, USA). A homemade yoghurt set containing lyophilized $S$. thermophilus and Lactobacillus bulgaricus) were used as a reference (Alsa, Rueil-Malmaison, France). S. thermophilus 102303T, L. delbrueckii subsp. bulgaricus 104365, L. acidophilus 76.13, L. helveticus CNRZ 303 and Lactobacillus casei subsp. casei ATC 334 were obtained from our laboratory collection. Lactobacillus rhamnosus CRBIP 24.130 and Lactobacillus fermentum CRBIP 24.11 were obtained from the Pasteur Institute laboratories (Paris, France). Each activated culture was inoculated into MRS (Biokar Diagnostics, Beauvais, France), except for S. thermophilus inoculated in M17 and incubated at $37{ }^{\circ} \mathrm{C}$ for $12 \mathrm{~h}$. These cultures were then diluted to $10^{7} \mathrm{CFU} / \mathrm{mL}$ with $9 \mathrm{~g} / \mathrm{L}$ sterilized $\mathrm{NaCl}$ solution and used as the inoculum of each LAB.

\subsection{Preparation of milks and fermented products}

The total amount of proteins was fixed at $4.5 \mathrm{~g} / 100 \mathrm{~g}$ of fermented product. Therefore, the concentration in pea proteins were $0,0.45,0.9,1.35$ and $1.8 \mathrm{~g} / 100 \mathrm{~g}$ of fermented product. The mixtures of cow and pea milk, prepared as illustrated in Fig. 1, were inoculated with different starter cultures (Table 1 ), sampled in plastic flasks ( $40 \mathrm{~mL}$ in $45 \mathrm{~mL}$ flasks) and incubated at $37^{\circ} \mathrm{C}$ for $24 \mathrm{~h}$ and stored at $4{ }^{\circ} \mathrm{C}$.

\subsection{Product characterization}

\subsection{1. $\mathrm{pH}$ and titratable acidity measurements}

Changes in $\mathrm{pH}$ values during fermentation were determined every $2 \mathrm{~h}$ at room temperature using a calibrated $\mathrm{pH}$ electrode and a pH-meter (Vision 6071, JENCO Electronics LTD, Shanghai, China). Three kinetic parameters were calculated from the curve $\mathrm{pH}=\mathrm{f}$ (time), using Eq. (1):

$V \cdot \max =(d p H / d t)$

where $V \cdot \max ^{5}$ is the maximum acidification rate (mUnit $\mathrm{pH} / \mathrm{min}$ ). T.end ${ }^{6}$ was the time necessary to reach $\mathrm{pH} 4.7$ (hours); the value $\mathrm{pH}$ 4.7 was chosen because it is the $\mathrm{pH}$ at which gels begin to form. The value $\mathrm{pH} .12 \mathrm{~h}^{7}$ was the $\mathrm{pH}$ obtained after $12 \mathrm{~h}$ of fermentation (Unit $\mathrm{pH}) ; 12 \mathrm{~h}$ was selected because there were significant differences in $\mathrm{pH}$ values among the different mixtures (cow milk and pea milk) in most of the studied cultures. Titratable acidity was determined according to the Dornic degree $\left(\mathrm{D}^{\circ}\right)$ method (Robinson \& Wilbey, 1998). Three replicate experiments were carried out for each measurement.

\subsubsection{Syneresis measurement}

The degree of whey separation was determined according to a siphon method (Amatayakul, Sherkat, \& Shah, 2006). Syneresis after one, seven and 14 days of storage at $4{ }^{\circ} \mathrm{C}$ was measured in triplicate and expressed as a percentage of total weight of the product.

\subsubsection{Rheological analysis}

Rheological characteristics were evaluated by Texture Analyzer TA.HD plus (Stable Micro Systems, Godalming, England) with Exponent software version 6 . A single penetration test was performed using a cylindrical probe of $10 \mathrm{~mm}$ diameter, a $5 \mathrm{Kg}$-load cell with a return distance of $85 \mathrm{~mm}$, a test speed of $1.00 \mathrm{~mm} / \mathrm{s}$ and $9 \mathrm{~mm}$ as the distance of penetration. From the curve, four values were collected representing "Firmness": maximum force value, "Consistency": positive area under the curve, "Index of Viscosity/ Consistency": minimum force value and "Cohesiveness": negative area under the curve. This test was performed in triplicate after one, seven and 14 days of storage at $4{ }^{\circ} \mathrm{C}$.

\subsubsection{Sensory evaluation}

Ten training sessions were conducted with 12 panelists selected for their ability to detect tastes and odors in pea "yoghurt" as well as their verbal fluency. Two sessions were carried out to generate a preliminary list of attributes based on five samples selected from our products. This list was then reduced to obtain a final list based on the ISO 11035:1994 norm (ISO., 1994). The next four sessions were dedicated to training. Panelists agreed upon definitions, references and procedures for each attribute and were trained to rank different water and yoghurt solutions containing substances that conferred the required attributes. In the last three sessions, ten new products were presented in duplicate to determine whether the panel was homogeneous, discriminating and repeatable. Panelists had to rate the intensity of all attributes for each product on a structured interval scale ranging from 1 (low) to 10 (high). After

\footnotetext{
${ }^{5}$ Maximum acidification rate.

6 The time necessary to reach $\mathrm{pH} 4.7$.

7 The $\mathrm{pH}$ after $12 \mathrm{~h}$ of fermentation.
} 


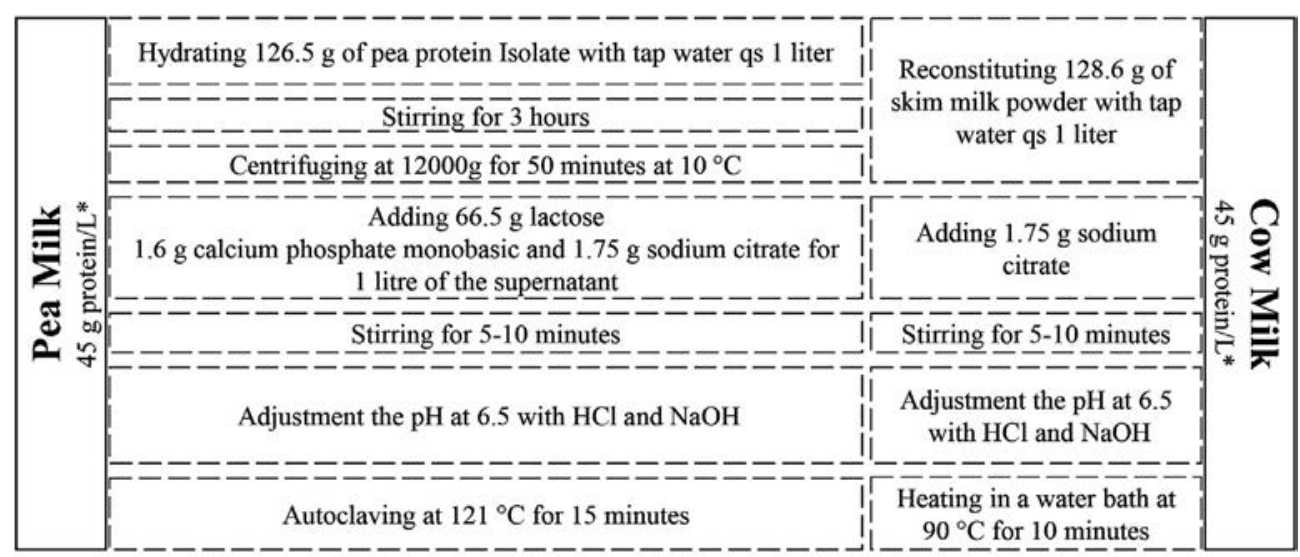

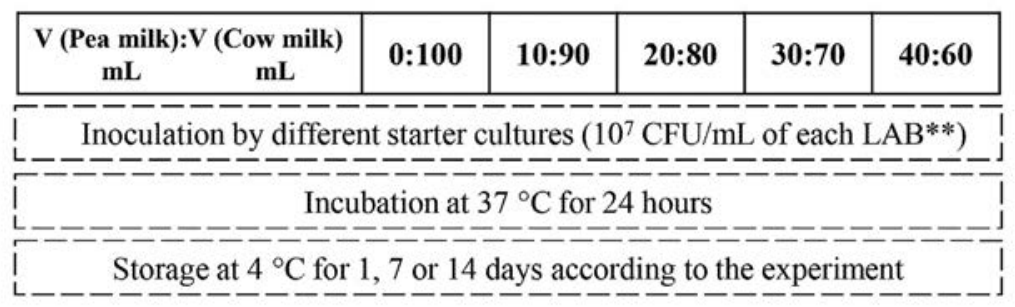

* Measured by Dumas method

** Lactic Acid Bacteria

Fig. 1. Preparation of pea milk, cow milk and fermented products.

Table 1

List of products: Capital letters label the bacteria cocktail used; numbers indicate pea protein concentration (g/100 g total protein).

\begin{tabular}{|c|c|c|c|c|c|c|}
\hline \multirow[b]{2}{*}{ A } & \multicolumn{5}{|c|}{ Products } & \multirow{2}{*}{$\begin{array}{l}\text { Starter culture } \\
\text { Alsa (Streptococcus thermophilus + Lactobacillus delbrueckii subsp. bulgaricus) }\end{array}$} \\
\hline & A00 & A10 & A20 & A30 & A40 & \\
\hline B & B00 & B10 & $\mathrm{B} 20$ & B30 & B40 & Streptococcus thermophilus + Lactobacillus delbrueckii subsp. bulgaricus \\
\hline $\mathrm{C}$ & $\mathrm{COO}$ & $\mathrm{C} 10$ & $\mathrm{C} 20$ & $\mathrm{C} 30$ & $\mathrm{C} 40$ & Streptococcus thermophilus + Lactobacillus helveticus \\
\hline $\mathrm{D}$ & D00 & D10 & D20 & D30 & D40 & Streptococcus thermophilus + Lactobacillus rhamnosus \\
\hline $\mathrm{E}$ & E00 & E10 & E20 & E30 & $\mathrm{E} 40$ & Lactobacillus delbrueckii subsp. Bulgaricus + Lactobacillus helveticus \\
\hline $\mathrm{F}$ & F00 & F10 & F20 & F30 & F40 & Streptococcus thermophilus + Lactobacillus acidophilus \\
\hline G & G00 & G10 & G20 & G30 & G40 & Lactobacillus delbrueckii subsp. Bulgaricus + Lactobacillus fermentum \\
\hline $\mathrm{H}$ & $\mathrm{HOO}$ & $\mathrm{H} 10$ & $\mathrm{H} 20$ & $\mathrm{H} 30$ & $\mathrm{H} 40$ & Streptococcus thermophilus + Lactobacillus casei subsp. casei \\
\hline I & 100 & $\mathrm{I} 10$ & $\mathrm{I} 20$ & $\mathrm{I} 30$ & 140 & Lactobacillus delbrueckii subsp. Bulgaricus + Lactobacillus rhamnosus \\
\hline $\mathrm{J}$ & $\mathrm{J} 00$ & $\mathrm{~J} 10$ & $\mathrm{~J} 20$ & $\mathrm{~J} 30$ & $\mathrm{~J} 40$ & Lactobacillus rhamnosus \\
\hline
\end{tabular}

training, 10 trained panelists (two participants abandoned the panel due to availability issues) evaluated the 50 products in duplicate.

\subsubsection{Statistical analysis}

In order to estimate the significance of differences between means, factorial ANOVAs ${ }^{8}$ were conducted, followed by a $\operatorname{LSD}^{9}$ test at the $5 \%$ level with Statistica version 10 (StatSoft, Tulsa, USA). Additionally, a PCA and a HCA were conducted with SPAD version 8.0 (Coheris, Suresnes, France).

\section{Results and discussion}

\subsection{Fermentative behavior}

Determining the acidifying capacity of starter culture is the classical way to estimate its activity. In this study, three kinetic

\footnotetext{
8 Analysis of variance.

9 Least significant difference.
}

parameters were considered: V.max, T.end and pH.12 h. The results concerning the effects of pea concentration and starter culture on the kinetic parameters and Dornic degree are summarized in Table 2.

The maximum acidification rate ranged from 1.58 to 15.33 mUnit $\mathrm{pH} / \mathrm{min}$ depending on pea ratio and bacteria cocktail. A minimum of $6.55 \mathrm{~h}$ was needed to obtain $\mathrm{pH} 4.7$, and this was not obtained in six samples, even after $24 \mathrm{~h}$ of fermentation. In this case, when fermentation is slow or the time to reach the desired $\mathrm{pH}$ is over $24 \mathrm{~h}$, it could be considered problematic for industrial applications as contamination may occur. According to Beal, Louvet, \& Corrieu, 1989, a medium rate of acidification is preferable because it results in non-excessive acid production, a more homogeneous structure of the coagulum and a greater viscosity of the final product.

ANOVAs showed that pea concentration, starter culture and the interaction between the two factors have significant effects on the three parameters of kinetics and the Dornic degree $(P<0.05)$. Globally, an increase in pea milk ratio caused a decrease in the time required to obtain a gel and an increase in the products' acidity. However, the effect of pea ratio was not linear for all bacteria 
Table 2

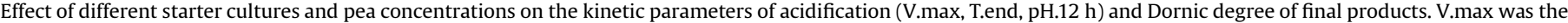
maximum acidification rate ( $\mathrm{mUnit} \mathrm{pH} / \mathrm{min}$ ), T.end was the time required to reach $\mathrm{pH}=4.7$ (hours) and $\mathrm{pH} .12 \mathrm{~h}$ was the $\mathrm{pH}$ obtained after $12 \mathrm{~h}$ of fermentation.

\begin{tabular}{|c|c|c|c|c|c|c|c|c|c|c|c|c|}
\hline $\begin{array}{l}\text { The } \\
\text { sample }\end{array}$ & $\begin{array}{l}\text { V.max } \\
\text { mUnit } \\
\mathrm{pH} / \mathrm{min}\end{array}$ & $\begin{array}{l}\text { T.end } \\
\text { hour }\end{array}$ & pH.12 h & $\begin{array}{l}\text { Dornic } \\
\text { degree }\end{array}$ & $\begin{array}{l}\text { The } \\
\text { sample }\end{array}$ & $\begin{array}{l}\text { V.max } \\
\text { mUnit } \\
\mathrm{pH} / \mathrm{min}\end{array}$ & $\begin{array}{l}\text { T.end } \\
\text { hour }\end{array}$ & pH.12 h & $\begin{array}{l}\text { Dornic } \\
\text { degree }\end{array}$ & $\begin{array}{l}\text { The } \\
\text { sample }\end{array}$ & $\begin{array}{l}\text { V.max } \\
\text { mUnit } \\
\mathrm{pH} / \mathrm{min}\end{array}$ & $\begin{array}{l}\text { T.end } \\
\text { hour }\end{array}$ \\
\hline A00 & $7.5 \pm 0.48$ & $7.1 \pm 0.06$ & $4.4 \pm 0.02$ & $93.4 \pm 2.52$ & $\mathrm{COO}$ & $3.1 \pm 0.39$ & a & $5.7 \pm 0.03$ & $140.8 \pm 3.47$ & E00 & $3.7 \pm 0.08$ & $15.2 \pm 0.03$ \\
\hline A10 & $7.6 \pm 0.40$ & $7.0 \pm 0.06$ & $4.3 \pm 0.01$ & $93.8 \pm 3.27$ & $\mathrm{C} 10$ & $2.3 \pm 0.15$ & $20.4 \pm 0.04$ & $5.6 \pm 0.01$ & $141.1 \pm 4.08$ & E10 & $4.0 \pm 0.17$ & $12.3 \pm 0.09$ \\
\hline A20 & $7.8 \pm 0.61$ & $6.6 \pm 0.04$ & $4.1 \pm 0.01$ & $102.1 \pm 4.01$ & $\mathrm{C} 20$ & $7.6 \pm 0.43$ & $10.8 \pm 0.06$ & $4.1 \pm 0.01$ & $147.6 \pm 2.23$ & E20 & $6.9 \pm 0.18$ & $6.6 \pm 0.06$ \\
\hline A30 & $7.1 \pm 0.34$ & $8.0 \pm 0.07$ & $4.4 \pm 0.02$ & $95.2 \pm 1.80$ & C30 & $6.7 \pm 0.19$ & $11.4 \pm 0.04$ & $4.4 \pm 0.02$ & $156.8 \pm 4.19$ & E30 & $4.9 \pm 0.15$ & $12.5 \pm 0.06$ \\
\hline A40 & $7.5 \pm 0.31$ & $9.0 \pm 0.09$ & $4.4 \pm 0.01$ & $101.7 \pm 3.48$ & $\mathrm{C} 40$ & $8.9 \pm 0.27$ & $11.3 \pm 0.04$ & $4.3 \pm 0.01$ & $146.5 \pm 3.76$ & $\mathrm{E} 40$ & $5.8 \pm 0.21$ & $8.2 \pm 0.04$ \\
\hline B00 & $4.7 \pm 0.43$ & $16.5 \pm 0.05$ & $5.0 \pm 0.01$ & $90.7 \pm 1.88$ & D00 & $15.3 \pm 0.25$ & $11.2 \pm 0.03$ & $3.9 \pm 0.02$ & $81.5 \pm 1.82$ & F00 & $2.7 \pm 0.11$ & a \\
\hline B10 & $5.6 \pm 0.32$ & $11.1 \pm 0.07$ & $4.4 \pm 0.02$ & $97.2 \pm 3.20$ & D10 & $15.0 \pm 0.24$ & $11.0 \pm 0.07$ & $3.8 \pm 0.01$ & $94.3 \pm 2.76$ & F10 & $2.7 \pm 0.16$ & a \\
\hline B20 & $8.5 \pm 0.23$ & $10.4 \pm 0.06$ & $3.9 \pm 0.01$ & $105.3 \pm 3.16$ & D20 & $10.7 \pm 0.21$ & $10.5 \pm 0.05$ & $3.7 \pm 0.02$ & $96.5 \pm 3.63$ & F20 & $4.0 \pm 0.15$ & $21.2 \pm 0.07$ \\
\hline B30 & $7.3 \pm 0.34$ & $10.7 \pm 0.07$ & $4.1 \pm 0.01$ & $100.6 \pm 4.55$ & D30 & $10.2 \pm 0.21$ & $10.4 \pm 0.07$ & $3.7 \pm 0.02$ & $98.3 \pm 2.46$ & F30 & $5.2 \pm 0.11$ & $19.7 \pm 0.07$ \\
\hline B40 & $6.4 \pm 0.29$ & $10.2 \pm 0.04$ & $4.0 \pm 0.02$ & $106.0 \pm 1.17$ & D40 & $8.7 \pm 0.23$ & $10.2 \pm 0.08$ & $3.7 \pm 0.02$ & $94.9 \pm 4.98$ & F40 & $6.2 \pm 0.14$ & $19.7 \pm 0.09$ \\
\hline
\end{tabular}

cocktails. The LSD test showed that the most acidifying group includes two starter cultures. Starter cultures C and E exhibit the highest Dornic degrees: these are the two starters containing " $L$. helveticus" that is known to have the most efficient proteolytic system among the LAB species (Griffiths \& Tellez, 2013). It is also one of the most used LAB species for lactic acid production because

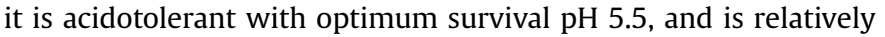
insensitive to product inhibition by lactic acid (Roy, Leduy, \& Goulet, 1987). On the other extreme, starter culture F (S. thermophilus + L. acidophilus) produced the lowest acidity.

\subsection{Syneresis}

Syneresis is considered as a defect that may be reduced by increasing the level of milk solids, especially protein (Tamime \& Deeth, 1980) or by using starter cultures producing exopolysaccharides that help decrease the level of liquid separation (Hassan, Frank, Schmidt, \& Shalabi, 1996). The amounts of liquid separation resulting from the different mixtures and starter cultures after one, seven and 14 days of storage at $4{ }^{\circ} \mathrm{C}$ are presented in Fig. 2. Syneresis values ranged from 0.22 to $4.65 \%$ after 1 -day storage, from 0.32 to $7.82 \%$ after 7-day storage and from 0.83 to 8.5\% after 14-day storage. Factorial ANOVA showed that pea concentration, starter culture and the interaction between the two factors had significant effects on syneresis $(P<0.05)$. Additionally, the increase in pea protein seemed to favor syneresis in most samples. For the highest pea milk ratio, only two starters (A and E) gave gels with syneresis levels of less than 5\% after 14-day storage. No correlation was found between the parameters of acidification and syneresis. Thus, fast acidification did not produce a gel characterized by more syneresis.

Although the phenomena occurring during syneresis are not fully understood, it is agreed that increased syneresis with storage time is usually associated with major casein network rearrangements (Van Vliet, Lucey, Grolle, \& Walstra, 1997), that promote whey expulsion. In our study, the same phenomena may be at work with the possible protein network composed of pea and cow milk proteins.

\subsection{Rheological properties}

The products were submitted to a penetration test after three different storage times at $4{ }^{\circ} \mathrm{C}$. As expected, firmness was correlated with consistency $\left(\mathrm{R}^{2}=0.935\right)$ and anti-correlated with the viscosity/consistency index $\left(\mathrm{R}^{2}=0.794\right)$. Factorial ANOVA showed that the firmness of products after 14 days of storage was significantly higher than that after one and seven days of storage
$(\mathrm{P}<0.05)$. Additionally, ANOVA showed that starter cultures, pea concentration and the interaction between them had significant effects on rheological parameters $(P<0.05)$. For purposes of clarity, only results concerning firmness after 14 days of storage at $4{ }^{\circ} \mathrm{C}$ are presented in Fig. 3. For all starter cultures, the presence of pea milk induced a decrease in firmness. The highest decrease in firmness was observed with the $\mathrm{H}$ starter culture in yoghurts without pea milk and in those with $40 \mathrm{~g}$ pea protein/100 g total protein at 14 days of storage. Fig. 4 shows the values of product firmness in the two extreme conditions: 0 and $40 \mathrm{~g}$ pea protein/100 $\mathrm{g}$ total protein, 1 and 14 days of storage according to starter culture. In cow milk, product firmness increased with storage time. The gain in firmness during storage from 1 to 14 days was important in starter cultures $\mathrm{H}, \mathrm{I}, \mathrm{J}, \mathrm{A}$ and $\mathrm{B}$. In the presence of $40 \mathrm{~g}$ pea protein/100 $\mathrm{g}$ total protein, product firmness was dramatically reduced. However, the gain in firmness during storage still occurred.

This increase in firmness can be explained by the post acidification residual activity of lactic bacteria in the products. The lactic acid production and the ability of strains to produce exopolysaccharides leads to the stabilization of casein micelles and a reinforcement of the strength of the protein network (GuzelSeydim, Sezgin, \& Seydim, 2005; Saint-Eve, Levy, Le Moigne, Ducruet, \& Souchon, 2008). The presence of pea protein did not favor the firmness of the products. Pea proteins seemed to hinder the implementation of the casein network, given the assumption that the milk protein network (casein and whey) may be formed first. Thus, the coagulum of pea protein may settle into the free spaces in the casein network and weaken it. Indeed, the possible molecular interactions between pea globulins and casein are not clearly established in the literature. Especially in dairy products, the structure of the gel composed of plant proteins, casein and whey protein is not fully understood. Certain authors have reported that the firmness or hardness of different fermented products increased with weak supplements of plant ingredients: up to $3 \%$ lentil flour in yoghurt (Zare et al., 2011), up to $8 \%$ sesame protein isolate in soft cheese (Lu, Schmitt, \& Chen, 2010), up to 3\% soy protein in rennet curd formation "Mozzarella" (Hsieh, Yun, \& Rao, 1993). On the contrary, greater pulse supplementation leads to a more fragile coagulum and so to a lesser degree of firmness or "hardness": $20 \%$ soy protein in rennet curd formation (Lee \& Marshall, 1979), 12\% sesame protein isolate in soft cheese (Lu et al., 2010). The last authors reported that sesame proteins in low concentration aggregated as clusters of small poly-particles covering the surface of cheese fractures, but when sesame concentration increased, the sesame protein aggregated as a different protein phase in the casein gel matrix. 


\begin{tabular}{|c|c|c|c|c|c|c|c|c|c|c|c|}
\hline pH.12 h & $\begin{array}{l}\text { Dornic } \\
\text { degree }\end{array}$ & $\begin{array}{l}\text { The } \\
\text { sample }\end{array}$ & $\begin{array}{l}\text { V.max } \\
\text { mUnit } \\
\mathrm{pH} / \mathrm{min}\end{array}$ & $\begin{array}{l}\text { T.end } \\
\text { hour }\end{array}$ & pH.12 h & $\begin{array}{l}\text { Dornic } \\
\text { degree }\end{array}$ & $\begin{array}{l}\text { The } \\
\text { sample }\end{array}$ & V.max mUnit $\mathrm{pH} / \mathrm{min}$ & $\begin{array}{l}\text { T.end } \\
\text { hour }\end{array}$ & pH.12 h & Dornic degree \\
\hline $4.8 \pm 0.03$ & $107.5 \pm 4.20$ & G00 & $6.3 \pm 0.10$ & $8.7 \pm 0.06$ & $3.9 \pm 0.03$ & $89.3 \pm 3.96$ & I00 & $1.6 \pm 0.06$ & a & $5.8 \pm 0.03$ & $100.1 \pm 4.94$ \\
\hline $4.7 \pm 0.03$ & $133.4 \pm 2.76$ & G10 & $5.8 \pm 0.14$ & $8.8 \pm 0.10$ & $4.1 \pm 0.02$ & $106.2 \pm 2.01$ & $\mathrm{I} 10$ & $2.3 \pm 0.08$ & a & $5.5 \pm 0.04$ & $118.1 \pm 6.91$ \\
\hline $4.2 \pm 0.03$ & $171.4 \pm 3.09$ & G20 & $6.4 \pm 0.04$ & $8.6 \pm 0.07$ & $3.9 \pm 0.01$ & $113.8 \pm 3.47$ & $\mathrm{I} 20$ & $3.2 \pm 0.13$ & a & $5.2 \pm 0.04$ & $124.6 \pm 4.48$ \\
\hline $4.7 \pm 0.01$ & $162.2 \pm 3.46$ & G30 & $6.2 \pm 0.12$ & $8.5 \pm 0.04$ & $3.8 \pm 0.02$ & $114.1 \pm 4.30$ & $\mathrm{I} 30$ & $3.0 \pm 0.11$ & $22.6 \pm 0.08$ & $5.2 \pm 0.06$ & $127.6 \pm 4.48$ \\
\hline $4.3 \pm 0.02$ & $159.5 \pm 5.53$ & G40 & $6.0 \pm 0.16$ & $8.7 \pm 0.05$ & $3.9 \pm 0.03$ & $110.7 \pm 4.39$ & $\mathrm{I} 40$ & $3.9 \pm 0.10$ & $22.7 \pm 0.09$ & $5.0 \pm 0.04$ & $128.9 \pm 6.17$ \\
\hline $5.6 \pm 0.01$ & $68.6 \pm 2.19$ & $\mathrm{HOO}$ & $2.8 \pm 0.12$ & $17.7 \pm 0.06$ & $5.1 \pm 0.04$ & $91.3 \pm 2.88$ & $\mathrm{~J} 00$ & $3.8 \pm 0.05$ & $22.7 \pm 0.09$ & $5.6 \pm 0.01$ & $91.4 \pm 3.81$ \\
\hline $5.4 \pm 0.02$ & $62.5 \pm 3.51$ & $\mathrm{H} 10$ & $3.3 \pm 0.13$ & $14.5 \pm 0.06$ & $4.9 \pm 0.03$ & $92.3 \pm 3.47$ & J10 & $4.7 \pm 0.05$ & $21.3 \pm 0.04$ & $5.4 \pm 0.03$ & $98.3 \pm 4.78$ \\
\hline $5.2 \pm 0.03$ & $69.3 \pm 2.62$ & $\mathrm{H} 2 \mathrm{O}$ & $2.8 \pm 0.05$ & $16.5 \pm 0.05$ & $5.0 \pm 0.05$ & $95.6 \pm 2.87$ & $\mathrm{~J} 20$ & $4.3 \pm 0.08$ & $18.1 \pm 0.12$ & $5.4 \pm 0.02$ & $107.8 \pm 4.41$ \\
\hline $5.1 \pm 0.01$ & $74.9 \pm 5.73$ & $\mathrm{H} 30$ & $3.3 \pm 0.11$ & $12.7 \pm 0.05$ & $4.8 \pm 0.03$ & $101.2 \pm 2.88$ & $\mathrm{~J} 30$ & $4.8 \pm 0.05$ & $17.4 \pm 0.05$ & $5.1 \pm 0.05$ & $113.0 \pm 4.41$ \\
\hline $4.9 \pm 0.02$ & $69.8 \pm 2.65$ & $\mathrm{H} 40$ & $4.0 \pm 0.10$ & $12.4 \pm 0.06$ & $4.7 \pm 0.03$ & $101.7 \pm 3.35$ & $\mathrm{~J} 40$ & $4.6 \pm 0.07$ & $15.3 \pm 0.09$ & $5.0 \pm 0.03$ & $106.7 \pm 3.42$ \\
\hline
\end{tabular}

Means followed by the confidence intervals $a=0.05$.

a Indicates samples in which $\mathrm{pH} 4.7$ was not achieved even after $24 \mathrm{~h}$.

\subsection{Sensory profile}

The sensory profiles of the 49 formulated products were compared with the profile of cow milk fermented with a commercial lactic bacteria starter (Alsa). The lexicon included three odor (vinegar, earth, vegetal), three aroma (smoked, dairy, pea), three taste (in mouth: bitter, acid, and sweet), and two mouthfeel (creamy, astringency) attributes. Vinegar, earth, vegetal, astringency, bitter, acid, smoked and pea were regarded as negative descriptors for the overall smell and taste in yoghurt, whereas creamy, sweet and dairy were regarded as positive descriptors. A three-way repeated ANOVA measurement with panelists as a random factor and pea concentrations and starters as fixed factors showed a significant effect of bacteria starters for all descriptors except smoked (Table 3). Globally, bacteria starters A, G, D and J tended to have higher intensities for positive descriptors such as creamy, dairy and sweet, and lower intensities for negative descriptors such as vegetal, earth and vinegar. On the other hand, bacteria starters E, I and $\mathrm{C}$ were associated with higher intensities for negative descriptors

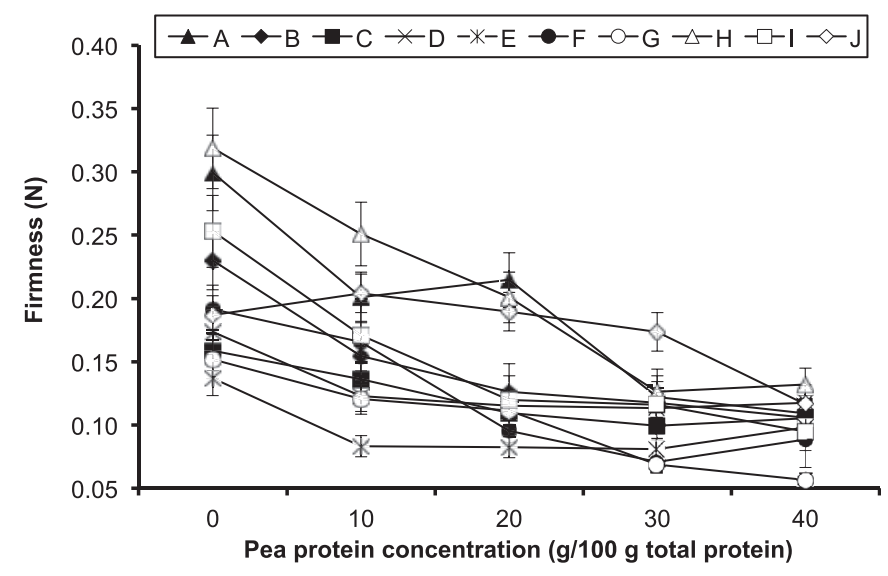

Fig. 3. The firmness of products after 14 days of storage at $4{ }^{\circ} \mathrm{C}$, according to the starter culture and the pea protein concentration ( $\mathrm{g} / 100 \mathrm{~g}$ total protein).
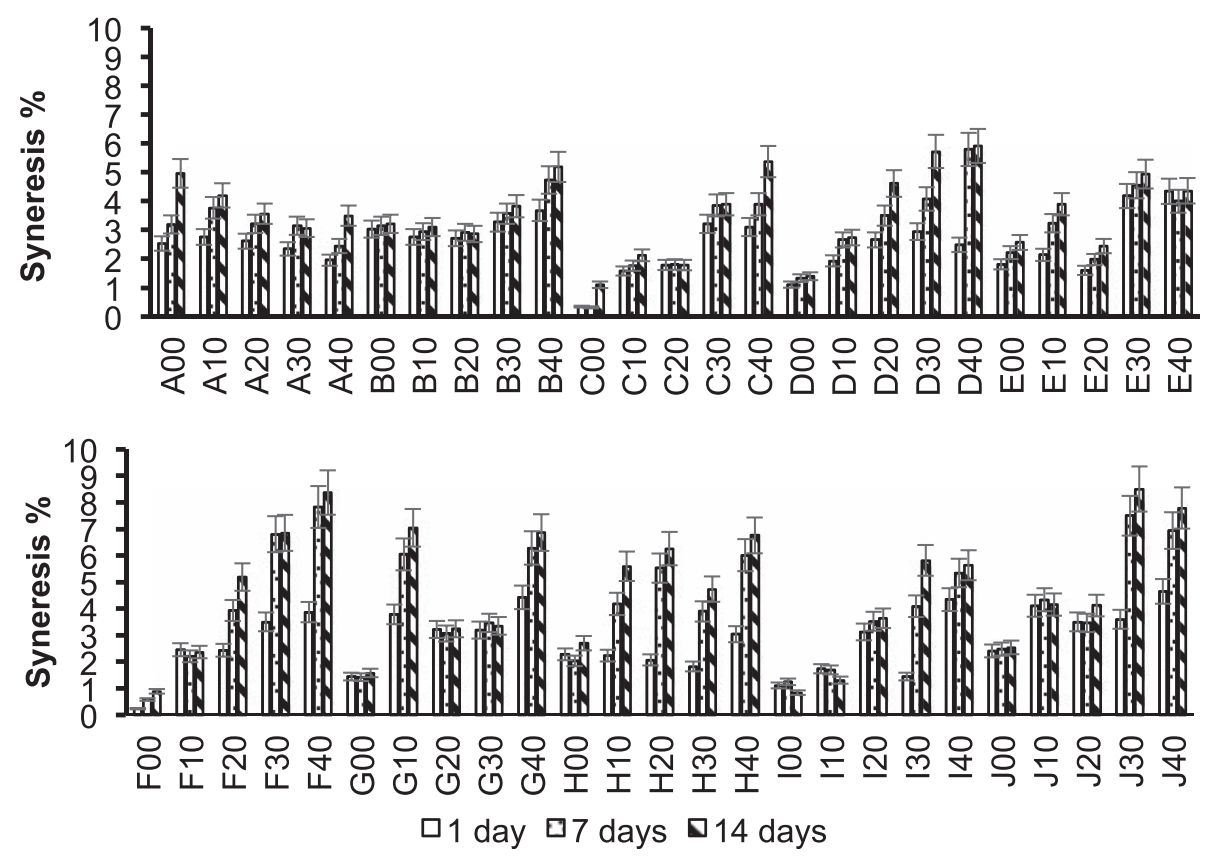

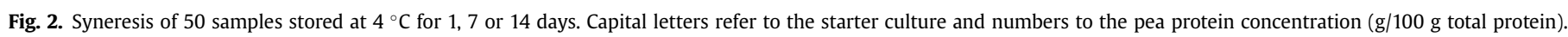




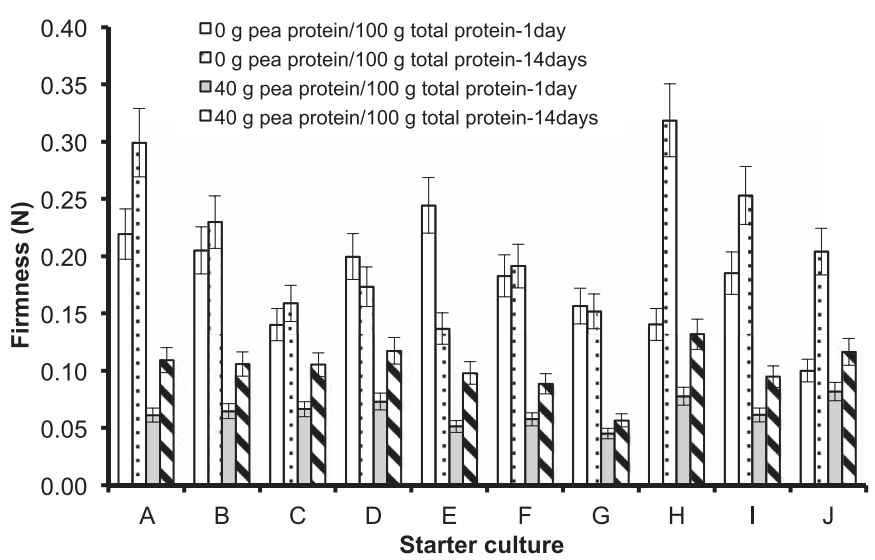

Fig. 4. Values for the firmness of products made with 0 and $40 \mathrm{~g}$ pea protein/100 $\mathrm{g}$ total protein at 1 and 14 days of storage at $4{ }^{\circ} \mathrm{C}$.

such as acid and astringent but rather low intensities for the negative descriptors pea and earth. Bacteria starters such as A, D and $\mathrm{J}$, which are associated with the highest intensities in negative descriptors such as pea or vegetal, also have high positive effects, leading to descriptors such as creamy. A significant effect of pea concentration was also found for seven descriptors (vinegar, earth, creamy, acid, smoked, dairy and pea). Among these descriptors, as expected, the intensity of the negative descriptors pea, earth, vinegar, and smoked increased with pea concentration, whereas the intensity of the positive descriptors creamy and dairy decreased with pea concentration. In addition to these main effects, significant interactions between starter culture and pea concentration were found for all descriptors except dairy and vegetal. An effect of pea concentration was observed for five negative descriptors (earth, smoked, pea, acid and fluid) as well as for one positive descriptor (creamy) for most starter cultures. As for the other descriptors (vinegar, bitter, sweet and astringent), we observed a pea concentration effect in only a small number of starter cultures.

\subsection{PCA and HCA for all measurements}

Fig. 5a, b, c and d represent the first three PCA dimensions (70.27\% of total variance). The first dimension (37.48\% of variance) opposes the negative aroma attributes pea, earth and smoked as well as the negative texture attributes fluid, viscosity and cohesiveness to the positive aroma attribute dairy and positive texture properties firmness and consistency. It represents a gradient in pea concentration ranging from $0 \mathrm{~g}$ to $40 \mathrm{~g}$ pea protein/100 g total protein. Negative attributes are mostly associated with the highest pea concentration products and positive attributes to the products without pea protein. The second dimension ( $18.99 \%$ of variance) opposes the sweetness attribute to the negative attributes astringent, acid and bitter. It opposes starter cultures $A$ and D yielding positive attributes to starter cultures $E$ yielding negative attributes, independently of pea concentration. The third dimension $(13.80 \%$ of variance) opposes the kinetic parameters of acidification: V.max, T.end and pH.12. It opposes starter cultures $A$ and $D$ yielding good acidification profiles to starter cultures $F$ and $G$ yielding negative profiles, independently of pea concentration.

The HCA performed on the first three PCA dimensions showed that the 50 products $(49+$ control $)$ could be divided into five classes (Table $4 \&$ Fig. 5). The first class includes five products, four of them without pea protein. These products are characterized by good texture and were described with positive attributes similar to the attributes of traditional yoghurts usually consumed by the panel (Tu et al., 2010). Moreover, the fifth product in this group, fermented by traditional bacteria starter $\mathrm{A}$, has the same texture as traditional yoghurt and is neither bitter nor astringent although it is composed of $10 \mathrm{~g}$ pea protein/100 $\mathrm{g}$ total protein. The second class includes 11 products, six of them without pea protein and five with only $10 \mathrm{~g}$ pea protein/100 $\mathrm{g}$ total protein. This group was described as having dairy and creamy characteristics as well as good firmness. Also, the negative properties of this group, such as long fermentation time and bitter taste, could be related to starter culture. The third group is composed of five products associated with the negative characteristics vinegar, astringent, acid and bitter and with the absence of dairy taste. This third group includes products fermented with just two starter cultures, E (L. delbrueckii subsp. Bulgaricus + L. helveticus) and I (L. delbrueckii subsp. Bulgaricus $+L$. rhamnosus) with the only Bacillus without Coccus. The fourth class includes 18 products with $10,20,30$ or 40 g pea protein/100 g total protein, with only negative sensory characteristics such as pea, earthy and smoked taste and negative rheological characteristics such as low values of firmness and consistency. The promising fifth class includes products without negative sensory characteristics. Although this class contains 8 from 11 products with $30 \%$ or $40 \%$ pea and without products $0 \%$ pea protein, the average notes (10point scale from low to high) of acid, astringent and bitter attributes in this class were 2.8, 3.3 and 2.4 instead of 4,4 and 3 in overall average.

\section{Conclusion}

The partial substitution of milk protein with pea protein did not enhance the physico-chemical characteristics of the dairy gels studied. In order to improve the firmness of these fermented products, a study on the procedure of preparation that may favor the interactions between pea and milk proteins must be performed.

Table 3

The effect of starter culture, pea concentration and the interaction between starter culture and pea concentration on sensory profile by using three-way ANOVA.

\begin{tabular}{|c|c|c|c|c|c|c|}
\hline & \multicolumn{2}{|c|}{ Starter culture } & \multicolumn{2}{|c|}{ Pea concentration } & \multicolumn{2}{|c|}{ Starter \& pea interaction } \\
\hline & F value & $\operatorname{Pr}>F$ & F value & $\operatorname{Pr}>F$ & F value & $\operatorname{Pr}>\mathrm{F}$ \\
\hline Odor vinegar & 5.54 & $<0.0001$ & 2.92 & 0.0343 & 1.73 & 0.0076 \\
\hline Odor earth & 2.57 & 0.0121 & 8.66 & $<0.0001$ & 1.73 & 0.0074 \\
\hline Odor vegetable & 5.32 & $<0.0001$ & 2.41 & 0.0675 & 1.42 & 0.0615 \\
\hline Texture creamy & 7.96 & $<0.0001$ & 10.12 & $<0.0001$ & 5.49 & $<0.0001$ \\
\hline Sensation astringent & 4.73 & $<0.0001$ & 1.05 & 0.3950 & 1.50 & 0.0387 \\
\hline Taste sweet & 7.48 & $<0.0001$ & 1.16 & 0.3443 & 2.77 & $<0.0001$ \\
\hline Taste bitter & 3.21 & 0.0023 & 2.66 & 0.0485 & 1.50 & 0.0386 \\
\hline Taste acid & 29.14 & $<0.0001$ & 4.42 & 0.0052 & 4.39 & $<0.0001$ \\
\hline Aroma smoked & 1.20 & 0.3041 & 24.31 & $<0.0001$ & 1.56 & 0.0249 \\
\hline Aroma dairy & 2.88 & 0.0055 & 17.28 & $<0.0001$ & 1.17 & 0.2377 \\
\hline Aroma pea & 6.03 & $<0.0001$ & 36.17 & $<0.0001$ & 1.68 & 0.0113 \\
\hline
\end{tabular}



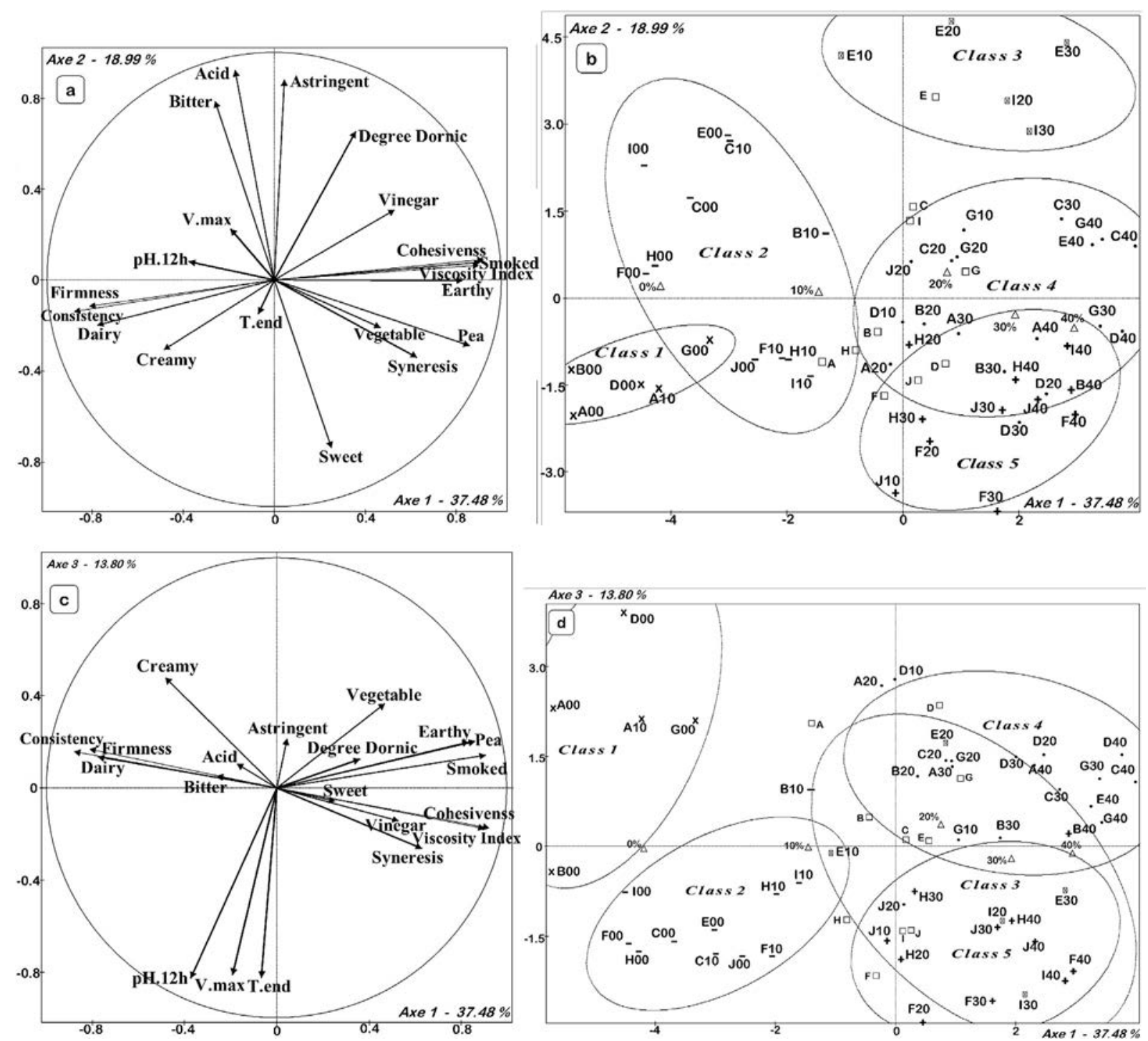

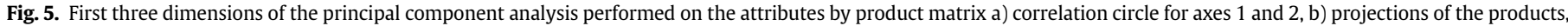

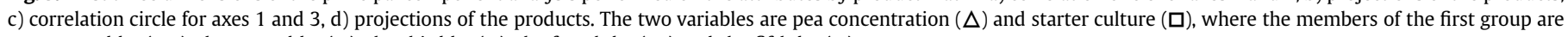
represented by $(\times)$, the second by $(-)$, the third by $($ 图), the fourth by $(\bullet)$ and the fifth by $(+)$.

Moreover, future investigations are needed to understand the architecture of the pea/milk protein network. From the sensory point of view, the substitution of animal protein with pea protein dramatically reduced the quality of products regarding their texture and flavor profiles. Whatever the strain, the intensity of five negative descriptors increased with the pea protein ratio. In these

Table 4

The characteristics of the five classes of hierarchical cluster analysis performed on the first three dimensions of the principal component analysis.

\begin{tabular}{|c|c|c|c|c|c|c|c|c|c|}
\hline \multicolumn{2}{|l|}{ Class 1} & \multicolumn{2}{|l|}{ Class 2} & \multicolumn{2}{|l|}{ Class 3} & \multicolumn{2}{|l|}{ Class 4} & \multicolumn{2}{|l|}{ Class 5} \\
\hline \multicolumn{2}{|c|}{$\mathrm{A} 00-\mathrm{A} 10-\mathrm{B} 00-\mathrm{D} 00-\mathrm{G} 00$} & \multicolumn{2}{|c|}{$\begin{array}{l}\text { B10-C00-C10-E00-F00 } \\
- \text { F10-H00-H10-I00-I10 } \\
\text {-J00 }\end{array}$} & \multicolumn{2}{|c|}{ E10-E20-E30-I20-I30 } & \multicolumn{2}{|c|}{$\begin{array}{l}\text { A20-A30-A40-B20-B30-C20 } \\
- \text { C 30-C40-D10-D20-D30-D40 } \\
-E 40-G 10-G 20-G 30-G 40-J 20\end{array}$} & \multicolumn{2}{|c|}{$\begin{array}{l}\text { B40-F20-F30-F40-H20-H30-H40-I40 } \\
-\mathrm{J} 10-\mathrm{J} 30-\mathrm{J} 40\end{array}$} \\
\hline $\begin{array}{l}\text { Over- } \\
\text { represented } \\
\text { variable }\end{array}$ & $\begin{array}{l}\text { Under- } \\
\text { represented } \\
\text { variable }\end{array}$ & $\begin{array}{l}\text { Over- } \\
\text { represented } \\
\text { variable }\end{array}$ & $\begin{array}{l}\text { Under- } \\
\text { represented } \\
\text { variable }\end{array}$ & $\begin{array}{l}\text { Over- } \\
\text { represented } \\
\text { variable }\end{array}$ & $\begin{array}{l}\text { Under- } \\
\text { represented } \\
\text { variable }\end{array}$ & $\begin{array}{l}\text { Over- } \\
\text { represented } \\
\text { variable }\end{array}$ & $\begin{array}{l}\text { Under-represented } \\
\text { variable }\end{array}$ & $\begin{array}{l}\text { Over-represented } \\
\text { Variable }\end{array}$ & $\begin{array}{l}\text { Under-represented } \\
\text { variable }\end{array}$ \\
\hline $\begin{array}{l}\text { Dairy } \\
\text { Firmness } \\
\text { Consistency } \\
\text { Creamy }\end{array}$ & $\begin{array}{l}\text { Earthy } \\
\text { V.max } \\
\text { Vinegar } \\
\text { Pea } \\
\text { Smoked } \\
\text { Cohesiveness } \\
\text { Viscosity In. }\end{array}$ & $\begin{array}{l}\text { pH.12 h } \\
\text { V.max } \\
\text { Consistency } \\
\text { Firmness } \\
\text { Bitter } \\
\text { dairy } \\
\text { T.end }\end{array}$ & $\begin{array}{l}\text { Vegetable } \\
\text { Viscosity In. } \\
\text { Cohesiveness } \\
\text { Syneresis } \\
\text { Earthy } \\
\text { Smoked } \\
\text { Pea }\end{array}$ & $\begin{array}{l}\text { Acid } \\
\text { Astringent } \\
\text { Dornic } \\
\text { Bitter } \\
\text { Vinegar }\end{array}$ & $\begin{array}{l}\text { Creamy } \\
\text { Dairy } \\
\text { Sweet }\end{array}$ & $\begin{array}{l}\text { Pea } \\
\text { Smoked } \\
\text { Earthy } \\
\text { Vegetable } \\
\text { Viscosity In. } \\
\text { Cohesiveness } \\
\text { Vinegar }\end{array}$ & $\begin{array}{l}\text { Consistency } \\
\text { Firmness } \\
\text { T.end } \\
\text { V.max } \\
\text { pH.12 h }\end{array}$ & $\begin{array}{l}\text { Syneresis } \\
\text { T.end } \\
\text { Sweet } \\
\text { Viscosity In. } \\
\text { Cohesiveness }\end{array}$ & $\begin{array}{l}\text { Consistency } \\
\text { Acid } \\
\text { Astringent } \\
\text { Bitter }\end{array}$ \\
\hline
\end{tabular}


conditions, the products composed of more than $20 \mathrm{~g}$ pea protein/ $100 \mathrm{~g}$ total protein were far removed from the sensory profile of conventional yoghurts. Considering both the sensory characteristics and fermentation parameters, four starter cultures (A, B, F and $\mathrm{H})$ seem promising for the production of yoghurts with pea proteins. It should be noted that these four starters all contain $S$. thermophilus.

\section{Acknowledgments}

The authors gratefully acknowledge A. Fusaro, C. Lucet, E. Tournemine, F. Gora and J. Huard, who helped to realize the sensory profile. The authors also thank M. Bouley for revising the English version of the manuscript. M. Yousseef thankfully acknowledges the Syrian Ministry of Higher Education for a Ph.D. fellowship that this work is a part of.

\section{References}

Aiking, H., de Boer, J., \& Vereijken, J. (2006). Sustainable protein production and consumption: Pigs or peas?: Pigs or peas? (Vol. 45). Springer Science \& Business Media.

Amatayakul, T., Sherkat, F., \& Shah, N. P. (2006). Syneresis in set yogurt as affected by EPS starter cultures and levels of solids. International Journal of Dairy Technology, 59(3), 216-221.

Beal, C., Louvet, P., \& Corrieu, G. (1989). Influence of controlled pH and temperature on the growth and acidification of pure cultures of Streptococcus thermophilus 404 and Lactobacillus bulgaricus 398. Applied Microbiology and Biotechnology, 32(2), 148-154.

Boland, M. J., Rae, A. N., Vereijken, J. M., Meuwissen, M. P. M., Fischer, A. R. H., van Boekel, M. A. J. S.... Hendriks. (January 2013). The future supply of animalderived protein for human consumption. Trends in Food Science and Technology, 29(1), 62-73. http://dx.doi.org/10.1016/j.tifs.2012.07.002.

Boye, J., Zare, F., \& Pletch, A. (2010). Pulse proteins: processing, characterization, functional properties and applications in food and feed. Food Research Inter national, 43(2), 414-431.

Champagne, C. P., Green-Johnson, J., Raymond, Y., Barrette, J., \& Buckley, N. (2009) Selection of probiotic bacteria for the fermentation of a soy beverage in combination with Streptococcus thermophilus. Food Research International, 42(5), 612-621.

Drake, M. A., Chen, X. Q., Tamarapu, S., \& Leenanon, B. (2000). Soy protein fortification affects sensory, chemical, and microbiological properties of dairy yogurts. Journal of Food Science, 65(7), 1244-1247.

El Soda, M., Abd El Wahab, H., Ezzat, N., Desmazeaud, M. J., \& Ismail, A. (1986). The esterolytic and lipolytic activities of the Lactobacilli. II. Detection of the esterase system of Lactobacillus helveticus, Lactobacillus bulgaricus. Lactobacillus lactis and Lactobacillus acidophilus. Le Lait, 66(4), 431-443.

Griffiths, M. W., \& Tellez, A. M. (2013). Lactobacillus helveticus: the proteolytic system. Frontiers in Microbiology, 4(30), 1-9.

Guzel-Seydim, Z. B., Sezgin, E., \& Seydim, A. C. (2005). Influences of exopolysaccharide producing cultures on the quality of plain set type yogurt. Food Control, 16(3), 205-209.

Hansen, M., Jakobsen, H. B., \& Christensen, L. P. (2000). The aroma profile of frozen green peas used for cold or warm consumption. In P. Schieberle, \& K. H. Engel (Eds.), The 9th weurman flavour symposium proceedings: Frontiers of flavour science (pp. 69-73). Garching: Deutsche Forschungsanstalt für
Lebensmittelchemie.

Hassan, A. N., Frank, J. F., Schmidt, K. A., \& Shalabi, S. I. (1996). Textural properties of yogurt made with encapsulated nonropy lactic cultures. Journal of Dairy Science, 79(12), 2098-2103.

Hsieh, Y. I. N. L., Yun, J. J., \& Rao, M. A. (1993). Rheological properties of Mozzarella cheese filled with dairy, egg, soy proteins, and gelatin. Journal of Food Science, 58(5), 1001-1004.

ISO. 11035. (1994). Sensory analysis: identification and selection of descriptors for establishing a sensory profile by a multidimensional approach. International Organization for Standardization.

Lee, Y. H., \& Marshall, R. T. (1979). Rennet curd from milk plus soy protein mixtures. Journal of Dairy Science, 62(7), 1051-1057.

Leroy, F., \& De Vuyst, L. (2004). Lactic acid bacteria as functional starter cultures for the food fermentation industry. Trends in Food Science \& Technology, 15(2), 67-78.

Lu, X., Schmitt, D., \& Chen, S. (2010). Effect of sesame protein isolate in partial replacement of milk protein on the rheological, textural and microstructural characteristics of fresh cheese. International Journal of Food Science \& Technology, 45(7), 1368-1377.

Ma, Z. Boye, J. I., Simpson, B. K., Prasher, S. O., Monpetit, D. \& Malcolmson, L. (2011). Thermal processing effects on the functional properties and microstructure of lentil, chickpea, and pea flours. Food Research International, 44(8), 2534-2544.

Marilley, L., Ampuero, S., Zesiger, T., \& Casey, M. G. (2004). Screening of aromaproducing lactic acid bacteria with an electronic nose. International Dairy Journal, 14(10), 849-856.

Moslehishad, M., Mirdamadi, S., Ehsani, M. R., Ezzatpanah, H., \& MoosaviMovahedi, A. A. (2013). The proteolytic activity of selected lactic acid bacteria in fermenting cow's and camel's milk and the resultant sensory characteristics of the products. International Journal of Dairy Technology, 66(2), 279-285.

Murat, C., Bard, M.-H., Dhalleine, C., \& Cayot, N. (2013). Characterisation of odour active compounds along extraction process from pea flour to pea protein extract. Food Research International, 53(1), 31-41.

Robinson, R. K., \& Wilbey, R. A. (1998). Tests for acidity and chemical analysis in process control. In Cheesemaking Practice (pp. 81-97). Springer.

Roy, D., Leduy, A., \& Goulet, J. (1987). Kinetics of growth and lactic acid production from whey permeate by Lactobacillus helveticus. The Canadian Journal of Chemical Engineering, 65(4), 597-603.

Ruas-Madiedo, P., Hugenholtz, J., \& Zoon, P. (2002). An overview of the functionality of exopolysaccharides produced by lactic acid bacteria. International Dairy Journal, 12(2), 163-171.

Saint-Eve, A., Levy, C., Le Moigne, M., Ducruet, V., \& Souchon, I. (2008). Quality changes in yogurt during storage in different packaging materials. Food Chemistry, 110(2), 285-293.

Schneider, A., \& Lacampagne, J. P. (2000). Peas: a European production of proteinrich materials for feed and food. Industrial Proteins, 8(1), 3-6.

Swanson, B. (1990). Pea and lentil protein extraction and functionality. Journal of the American Oil Chemists' Society, 67(5), 276-280.

Tamime, A. Y., \& Deeth, H. C. (1980). Yogurt technology and biochemistry. Journal of Food Protection, 43(12), 939-977.

Tu, V. P., Valentin, D., Husson, F., \& Dacremont, C. (2010). Cultural differences in food description and preference: contrasting Vietnamese and French panellists on soy yogurts. Food Quality and Preference, 21(6), 602-610.

Van Vliet, T., Lucey, J. A., Grolle, K., \& Walstra, P. (1997). Rearrangements in acidinduced casein gels during and after gel formation. Special Publication-Royal Society Of Chemistry, 192, 335-345.

Wang, Y.-C., Yu, R.-C., \& Chou, C.-C. (2002). Growth and survival of bifidobacteria and lactic acid bacteria during the fermentation and storage of cultured soymilk drinks. Food Microbiology, 19(5), 501-508.

Zare, F., Boye, J. I., Orsat, V., Champagne, C., \& Simpson, B. K. (2011). Microbial, physical and sensory properties of yogurt supplemented with lentil flour. Food Research International, 44(8), 2482-2488. 